\title{
Combined assessment of low PGRMC1/positive ATP1A1 levels has enhanced prognostic value for renal cell carcinoma
}

\author{
$\mathrm{YU} \mathrm{HE}^{1 *}$, PENG ZHANG $^{2^{*}}$, DAN ZHANG ${ }^{1}$, ZIJING XIA $^{3}$, XIXI WANG ${ }^{1}$, SHI DENG $^{2}$, \\ HAOCHENG $\mathrm{LI}^{4}$, HONGXIA ZHU ${ }^{5}$, NINGZHI XU ${ }^{1,5}$ and SHUFANG LIANG ${ }^{1}$
}

\author{
${ }^{1}$ State Key Laboratory of Biotherapy and Cancer Center, West China Hospital, Sichuan University and Collaborative \\ Innovation Center for Biotherapy; ${ }^{2}$ Department of Urinary Surgery, West China Hospital, West China School of Medicine, \\ Sichuan University; ${ }^{3}$ Department of Nephrology, West China Hospital, Sichuan University, Chengdu, Sichuan 610041 , \\ P.R. China; ${ }^{4}$ Department of Mathematics and Statistics, University of Calgary, Calgary, AB T2N 1N4, Canada; \\ ${ }^{5}$ Laboratory of Cell and Molecular Biology and State Key Laboratory of Molecular Oncology, \\ Cancer Institute and Hospital, Chinese Academy of Medical Sciences, Beijing 100021, P.R. China
}

Received January 11, 2018; Accepted June 12, 2018

DOI: 10.3892/or.2018.6541

\begin{abstract}
Progesterone receptor membrane component 1 (PGRMC1) and $\mathrm{Na}^{+} / \mathrm{K}^{+}$-ATPase $\alpha 1$ subunit (ATP1A1) are two proteins associated with the clinical prognosis of renal cell carcinoma (RCC) and RCC cell proliferation. However, the two proteins have been previously studied independently, and their combined influence on the clinical outcome of RCC remains unclear. The present study suggests that the combined expression levels of PGRMC1 and ATP1A1 (PGRMC1/ATP1A1) are associated with the clinical prognosis of RCC patients. RCC patients with low PGRMC1/positive ATP1A1 levels exhibited the best overall survival (OS) outcomes (103.08 \pm 1.85 months). The high PGRMC1/negative ATP1A1 group demonstrated the worst prognosis (73.1 \pm 8.87 months). The low PGRMC1/positive ATP1A1 group had the highest 7-year OS rate (92.3\%). The high PGRMC1/negative ATP1A1 group had the lowest 7-year OS rate (46.7\%). Although PGRMC1 and ATP1A1 both act on AKT phosphorylation in RCC cells, their expression
\end{abstract}

Correspondence to: Dr Shufang Liang, State Key Laboratory of Biotherapy and Cancer Center, West China Hospital, Sichuan University and Collaborative Innovation Center for Biotherapy, 17 Section 3, People's South Road, Chengdu, Sichuan 610041, P.R. China

E-mail: zizi2006@scu.edu.cn

*Contributed equally

Abbreviations: PGRMC1, progesterone receptor membrane component 1; ATP1A1, $\mathrm{Na}^{+} / \mathrm{K}^{+}$-ATPase $\alpha 1$ subunit; OS, overall survival; IHC, immunohistochemistry; PKTs, autologous paracancerous kidney tissues; RCC, renal cell carcinoma; RCTs, RCC tissues

Key words: progesterone receptor membrane component 1 , $\mathrm{Na}^{+} / \mathrm{K}^{+}$-ATPase $\alpha 1$ subunit, combined evaluation, renal cell carcinoma levels are independent of each other. Moreover, the synergistic suppressive roles of PGRMC1 downregulation combined with ATP1A1 upregulation exhibit more efficient tumor inhibition potentials on RCC cells. Therefore, combined assessment of the two biomarkers (PGRMC1/ATP1A1) shows enhanced prognostic ability for RCC.

\section{Introduction}

Kidney cancer is liable for an estimated 295,000 newly diagnosed cases and 134,000 related deaths globally every year (1). Renal cell carcinoma (RCC) accounts for over $90 \%$ of all kidney cancer cases and is characterized by poor patient prognosis. Approximately $65 \%$ of RCC patients have localized tumors, which can be successfully treated by surgery, whereas $35 \%$ of RCC patients incur tumor relapse after surgery (2). $\mathrm{RCC}$ is relatively resistant to radiotherapy or chemotherapy. The existing molecular biomarkers are not effective for RCC diagnosis and prognosis. Therefore, it is critical to explore novel biomarkers.

Progesterone receptor membrane component 1 (PGRMC1) is a member of the membrane-associated progesterone receptor protein family. PGRMC1 is commonly overexpressed to promote tumor growth in multiple cancers (3), including ovarian (4), endometrial (5), breast (6), lung (7) and colorectal cancer (8). On the other hand, $\mathrm{Na}^{+} / \mathrm{K}^{+}$-ATPase $\alpha 1$ subunit (ATP1A1), a subunit of $\mathrm{Na}^{+} / \mathrm{K}^{+}$-ATPase, seems to have dual roles in cancer progression. For example, a high level of ATP1A1 expression presents in many cancer types (9-13), while ATP1A1 is decreased in prostate carcinoma and colorectal cancer (14-16).

Our previous studies have demonstrated that PGRMC1 and ATP1A1 are two novel potential biomarkers for $\operatorname{RCC}(17,18)$. PGRMC1 is increased in RCC tumor tissues compared with that noted in autologous paracancerous tissues. The upregulation has a positive association with RCC malignancy and poor patient survival outcome (17). ATP1A1 is significantly downregulated in RCC, and ATP1A1-positive RCC patients 
show a better overall survival (OS) than ATP1A1-negative patients (18). However, the combined influences of the two proteins have not been investigated in RCC. Since multiple biomarkers often outperform a single biomarker in terms of prognostic ability (19-25), we jointly analyzed the association between the two proteins and the prognosis of RCC patients.

Our study demonstrated that RCC patients with low PGRMC1 and positive ATP1A1 levels have the best overall survival, which was significantly longer than the other groups. We also confirmed that elevated PGRMC1 and downregulated ATP1A1 both activate AKT phosphorylation to enhance RCC cell growth and migration. The combined regulation of PGRMC1 downregulation and ATP1A1 upregulation exhibited synergistic tumor inhibitory effects on RCC cells. In general, the combined assessment of two biomarkers (PGRMC1 and ATP1A1) exhibits enhanced prognostic value for RCC.

\section{Materials and methods}

Cell lines. Renal cancer cells, OS-RC-2 and 786-O, were purchased from the American Type Culture Collection (ATCC; Manassas, VA, USA). Cells were cultured in RPMI-1640 medium (Corning Inc., Corning, NY, USA) as described in our previous studies $(17,18)$.

Tissue samples. All of the following manipulations were performed in full accordance with prior review, consent and approval provided by the Institutional Ethics Committee of the State Key Laboratory of Biotherapy, West China Hospital of Sichuan University. Eighty pairs of clear cell renal cell carcinoma tissues (RCTs) and their corresponding autologous paracancerous kidney tissues (PKTs) were obtained from RCC patients who underwent surgery at West China Hospital, Sichuan University (Chengdu, China) from July 2006 to February 2008. These patients included 44 men and 36 women. The average age was 59 years (range age, 29-82 years) and all patients did not receive radiotherapy, chemotherapy and immunotherapy prior to surgery. All tissues were identified through pathologic biopsy, and the tissues were frozen in liquid nitrogen. The RCC patient demographic and clinical information, including age, gender and histological type of tumor differentiation (26), was collected following provision of informed consent. The demographic and clinical information of the $80 \mathrm{RCC}$ patients was presented in our previous study (18). Follow-up information was obtained from review of the medical records of the patients.

Expression plasmids, siRNAs and cell transfection. The expression plasmids pFlag-PGRMC1 and pYR-ATP1A1 were constructed for exogenous overexpression of PGRMC1 and ATP1A1 in RCC OS-RC-2 and 786-O cells $(17,18)$. After RCC cells were seeded on a 6-well plate for culture overnight, cells were transiently transfected with $2.5 \mu \mathrm{g}$ pFlag-PGRMC1 or pYR-ATP1A1 plasmids per well using Invitrogen ${ }^{\mathrm{TM}}$ Lipofectamine 2000 (Thermo Fisher Scientific, Inc., Waltham, MA, USA).

The siRNA for PGRMC1 (siPGRMC1) was synthesized by the RiboBio Co. (RiboBio, Guangzhou, China). The
PGRMC1-specific siRNA sequences (siPGRMC1) were designed as 5'-CTGGGAGTCTCAGTTCACT-3', and negative control oligonucleotides (siNC) were 5'-UUCUCCGAACGU GUCACGU-3'. The OS-RC-2 and 786-O cells were seeded on a 6-well plate for incubation with $50 \mathrm{nM}$ siPGRMC1 or siNC per well using Invitrogen ${ }^{\mathrm{TM}}$ Lipofectamine 2000.

Western blot analysis. To detect the protein expression level, 60-80 $\mu \mathrm{g}$ proteins, extracted from cell pellets or tissues, were separated on a $10 \%$ SDS-PAGE gel to test by western blotting. The primary antibodies included PGRMC1 (1:500; cat. no. ab48012; Abcam, Cambridge, UK), ATP1A1 (1:200; cat. no. ab2872; Abcam), GAPDH (1:1,000; cat. no. sc-365062; Santa Cruz Biotechnology, Inc., Dallas, TX, USA), AKT (1:500; cat. no. 4961; Cell Signaling Technology, Inc., Danvers, MA, USA) and phosphorylated AKT (p-AKT, 1:500; cat. no. ab18206; Abcam). The HRP-conjugated secondary antibodies, including goat anti-rabbit (cat. no. ZB-2301; Beijing Zhongshan Golden Bridge Biotechnology, Co., Ltd., Beijing, China) and goat anti-mouse (cat. no. ZB-2305; Beijing Zhongshan Golden Bridge Biotechnology), were diluted at 1:10,000 for incubation with the PVDF membrane at $37^{\circ} \mathrm{C}$ for $1 \mathrm{~h}$. Final detection was performed with western blot analysis reagent ECL (Amersham Biosciences; GE Healthcare, Chicago, IL, USA).

Immunohistochemistry. Eighty pairs of RCTs and their corresponding PKTs were paraffin-embedded and cut into sections with 5- $\mu \mathrm{m}$ thickness for immunohistochemistry (IHC) analysis according to our previous procedures (27). Tissue sections were incubated with the primary antibody of ATP1A1 (1:400; cat. no. ab2872; Abcam), PGRMC1 (1:1,000; cat. no. ab48012; Abcam) and p-AKT (1:500; cat. no. ab18206; Abcam) at $37^{\circ} \mathrm{C}$ for $2 \mathrm{~h}$ followed by quenching the endogenous peroxidase activity and antigen retrieval. Subsequently, the sections were incubated with the secondary antibody, biotinylated anti-goat IgG (cat. no. ZB-2306; ZSGB-BIO; OriGene Technologies, Inc., Beijing, China) at $37^{\circ} \mathrm{C}$ for $40 \mathrm{~min}$, following reacting with 3,3'-diaminobenzidine substrate solution (Dako Cytomation $\mathrm{GmbH}$, Shanghai, China) and counterstaining with hematoxylin. Five independent fields at x200 magnification for positive cells were chosen to evaluate the immunostaining intensity and percentage. The staining intensity was defined as follows: 0 (negative), 1 (weak), 2 (moderate) and 3 (strong). The staining percentage was defined as follows: 0 (negative), $1(1-25 \%), 2(26-50 \%), 3(51-75 \%)$ and 4 (76-100\%). The IHC scores for each tissue sample, ranging from 0 to 12 , were measured as immunostaining intensity multiplied by the percentage of positive cells $(28,29)$. The expression levels of PGRMC1 and ATP1A1 were determined according to the final IHC scores $(17,18)$. Similarly, the p-AKT level in tissues was defined as low (scores <3) and high expression (scores 3-12).

Cell viability. Cell viability was measured by CCK-8 assay as previously described (30). The OS-RC-2 and 786-O cells were seeded on a 6 -well plate and incubated with $50 \mathrm{nM}$ siPGRMC1 or siNC per well. On the first day after siPGRMC1 treatment for RCC cells, cells were transfected with $2.5 \mu \mathrm{g}$ pYR-ATP1A1 plasmids to further observe cell growth (31). 
Table I. PGRMC1 and ATP1A1 expression in RCTs and PKTs.

\begin{tabular}{|c|c|c|c|c|c|c|}
\hline \multirow[b]{2}{*}{ Protein } & \multirow[b]{2}{*}{ Immuno-reactivity } & \multicolumn{2}{|c|}{ RCTs (n=80) } & \multicolumn{3}{|c|}{ PKTs $(\mathrm{n}=80)$} \\
\hline & & $\%($ n/total $)$ & Average score & $\%($ n/total $)$ & Average score & P-value \\
\hline \multirow[t]{3}{*}{ PGRMC1 } & Total & $100(80 / 80)$ & $5.56 \pm 2.94$ & $100(80 / 80)$ & $3.70 \pm 1.83$ & $<0.001$ \\
\hline & Low & $42.5(34 / 80)$ & $2.62 \pm 1.13$ & $77.5(62 / 80)$ & $2.89 \pm 0.99$ & \\
\hline & High & $57.5(46 / 80)$ & $7.74 \pm 1.69$ & $22.5(18 / 80)$ & $6.50 \pm 1.15$ & \\
\hline \multirow[t]{3}{*}{ ATP1A1 } & Total & $100(80 / 80)$ & $1.27 \pm 1.85$ & $100(80 / 80)$ & $8.35 \pm 2.96$ & $<0.001$ \\
\hline & Negative & $41.3(33 / 80)$ & 0 & $1.2(1 / 80)$ & 0 & \\
\hline & Positive & $58.7(47 / 80)$ & $2.16 \pm 1.98$ & $98.8(79 / 80)$ & $8.46 \pm 2.83$ & \\
\hline
\end{tabular}

Student's t-test, $\mathrm{P}<0.001$. RCTs, renal cell carcinoma tissues; PKTs, para-cancerous kidney tissues. \% (n/total) indicates the percentage (specific cases/total cases). The low PGRMC1 level was scored 1-4, while the high level was $>4$. The negative ATP1A1 level was scored 0, while the positive level was $>0$.

After $24 \mathrm{~h}, 5 \times 10^{3}$ cells/well were seeded in a 96 -well plate to culture for $24,48,72$ and $96 \mathrm{~h}$. Then, $10 \% \mathrm{CCK}-8$ reagent (ZP328-3; Zoman Biotechnology, Beijing, China) was added to incubate for another $2 \mathrm{~h}$ at $37^{\circ} \mathrm{C}$ to assess optical density (OD) values at $450 \mathrm{~nm}$. Three independent experiments were performed.

Cell migration. Cell migration was detected within a 24-well Transwell chamber system (PIEP12R48; EMD Millipore, Billerica, MA, USA) (28-30). The OS-RC-2 and 786-O cells were seeded on a 6-well plate for incubation with $50 \mathrm{nM}$ siPGRMC1 or siNC per well. After siPGRMC1 treatment for $24 \mathrm{~h}$, cells were transfected with $2.5 \mu \mathrm{g}$ pYR-ATP1A1 plasmids to culture for $48 \mathrm{~h}$. Then, $8 \times 10^{3}$ cells in $500 \mu \mathrm{l}$ serum-free RPMI-1640 medium were seeded in the upper chamber of the Transwell apparatus, and $500 \mu$ l RPMI-1640 medium with $10 \%$ FBS was supplemented in the bottom chamber. Migratory cells were fixed by methanol and stained with crystal violet. The migration cells were counted in five visual fields randomly selected from each membrane under an Olympus inverted microscope (Olympus Corp., Lake Success, NY, USA). Three independent experiments were performed. The data of experimental group and control group were input for statistical analysis.

Statistical analysis. RCC patients were divided into four groups based on PGRMC1 and ATP1A1 expression levels, including a high PGRMC1/negative ATP1A1 group $(n=15)$, low PGRMC1/positive ATP1A1 group $(n=16)$, low PGRMC1/negative ATP1A1 group $(n=18)$ and high PGRMC1/positive ATP1A1 group $(n=31)$. OS outcomes were evaluated by the Kaplan-Meier survival analysis method, with the log-rank test to compare groups. The Student's t test and post hoc test with ANOVA were used to compare the factors across groups. $\mathrm{P}<0.05$ was considered to indicate a statistically significant difference.

\section{Results}

Expression levels of PGRMC and ATPIAl in RCC. The protein expression levels of PGRMC1 and ATP1A1 are shown in three randomly selected RCTs and their counterparts (Fig. 1A). PGRMC1 was overexpressed in RCTs when compared with their corresponding PKTs, whereas ATP1A1 was largely decreased. We further detected expression levels of these two proteins in 80 pairs of RCTs and PKTs by IHC analysis (Table I). The results demonstrated that PGRMC1 had an upregulated expression in RCTs compared with PKTs, but ATP1A1 protein was significantly downregulated (Fig. 1B). The average immunoreactivity score of PGRMC1 was $5.56 \pm 2.94$ in $80 \mathrm{RCTs}$, which was higher than the average staining score $3.70 \pm 1.83$ in 80 corresponding PKTs $(\mathrm{P}<0.001)$. On the other hand, the IHC score of ATP1A1 was $1.27 \pm 1.85$ in 80 RCTs, which was significantly lower than the average staining score $8.35 \pm 2.96$ in 80 RCTs $(\mathrm{P}<0.001)$. The IHC scores and clinical information for the RCC cases are provided in detail in Table II.

Enhanced OS outcomes for RCC patients with low PGRMC1/positive ATP1Al levels. PGRMC1 and ATP1A1 are confirmed to be two proteins associated with RCC prognosis $(17,18)$. We further validated whether the combination of two biomarkers can have a more favorable prognostic performance than each biomarker alone.

We compared the combined clinical value of ATP1A1 and PGRMC1 with the single molecule evaluation in RCC prognosis. The Kaplan-Meier estimates showed significantly higher OS rates for the RCC patients with low PGRMC1/positive ATP1A1 than the other three groups. The individuals with low PGRMC1/positive ATP1A1 also had the longest average OS. Conversely, the patients with high PGRMC1/negative ATP1A1 had the worst average OS time (73.1 18.87 months, $\mathrm{P}=0.04$, Fig. 2). The 7-year OS rate of the low PGRMC1/positive ATP1A1 group was the highest of all groups $(92.3 \%)$. It was significantly higher than those patients with high PGRMC1/negative ATP1A1 (46.7\%, Table III).

Elevated PGRMCl and downregulated ATPIA1 both enhance $A K T$ phosphorylation in RCC cells. PGRMC1 promotes activation of the PI3K/AKT signaling pathway $(4,32)$. On the other hand, inhibitors of $\mathrm{Na}^{+} / \mathrm{K}^{+}$-ATPase can activate PI3K/AKT signaling pathways (33). We confirmed that the 


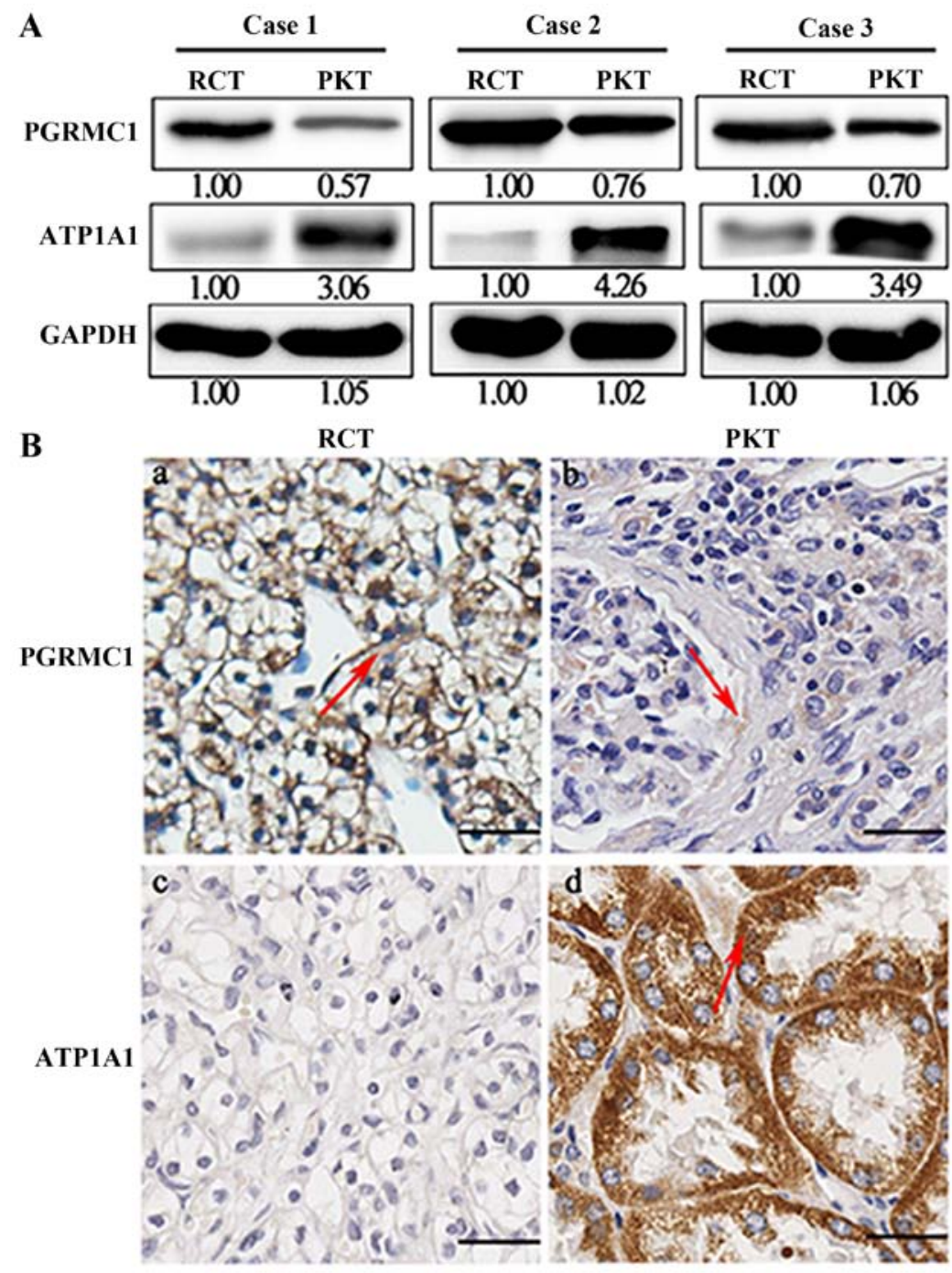

Figure 1. The expression levels of PGRMC1 and ATP1A1 in RCTs and PKTs were detected by (A) western blotting and (B) IHC. (A) The expression of PGRMC1 and ATP1A1 were measured in three randomly selected RCTs and their counterparts. (B) The staining activity of PGRMC1 and ATP1A1 were respectively shown in RCTs (a and c) and PKTs (b and d). The positive staining cells are shown with an arrow. RCTs, renal cell carcinoma tissues; PKTs, autologous para-cancerous kidney tissues; IHC, immunohistochemistry.

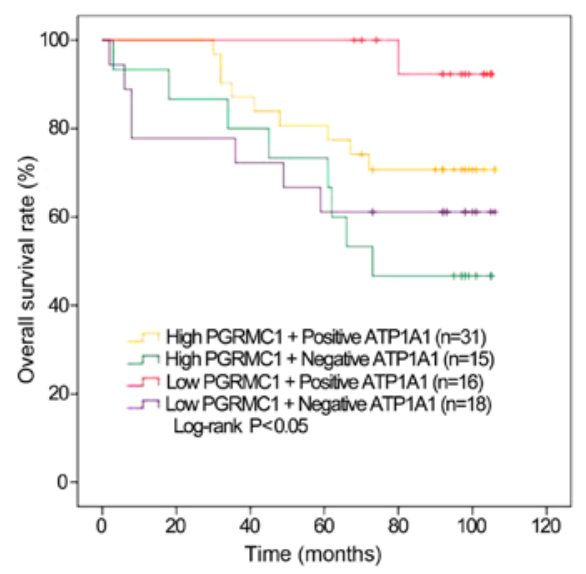

Figure 2. Higher OS rate for RCC patients with low PGRMC1/positive ATP1A1 levels. Eighty RCC patients who had exact OS rates were grouped into four types, including group 1 with high PGRMC1/negative ATP1A1 $(\mathrm{n}=15)$, group 2 with low PGRMC1/positive ATP1A1 ( $=16)$, group 3 with low PGRMC1/negative ATP1A1 ( $\mathrm{n}=18)$ and group 4 with high PGRMC1/positive ATP1A1 (n=31). The Kaplan-Meier estimates showed that patients with low PGRMC1/positive ATP1A1 had the highest survival rate through our analysis ( $\mathrm{P}=0.04$ by log-rank test). OS, overall survival; RCC, renal cell carcinoma.
ATP1A1-mediated Raf/MEK/ERK signaling pathway is suppressed in RCC cells (18). Therefore, we hypothesized that PGRMC1 and ATP1A1 could play a combined role in RCC development via AKT phosphorylation.

In OS-RC-2 and 786-O cells, when PGRMC1 expression was upregulated due to a transient transfection of pFlag-PGRMC1 plasmids for $48 \mathrm{~h}$, the relative level of p-AKT was also increased (Fig. 3A). In contrast, when PGRMC1 expression was suppressed by siRNA treatment for $48 \mathrm{~h}$, the p-AKT level was correspondingly decreased (Fig. 3A). However, the expression level of ATP1A1 was not significantly changed in response to PGRMC1 overexpression or knockdown. On the other hand, ATP1A1 upregulation by transient pYR-ATP1A1 transfections inhibited the p-AKT level in OS-RC-2 and 786-O cells (Fig. 3B), and there was no significant change in PGRMC1 expression when ATP1A1 was upregulated. In general, the expression levels of PGRMC1 and ATP1A1 are independent of each other, but elevated PGRMC1 and downregulated ATP1A1 both enhanced the p-AKT level in the RCC cells. 
Table II. Overall survival analysis of the combination of PGRMC1 and ATP1A1.

\begin{tabular}{|c|c|c|c|c|c|c|c|c|c|c|c|}
\hline \multirow{2}{*}{$\begin{array}{l}\text { Case } \\
\text { no. }\end{array}$} & \multirow{2}{*}{$\begin{array}{c}\text { Age } \\
\text { (years) }\end{array}$} & \multirow[b]{2}{*}{ Sex } & \multirow{2}{*}{$\begin{array}{l}\text { TNM } \\
\text { stage }\end{array}$} & \multirow{2}{*}{$\begin{array}{l}\text { Survival time } \\
\text { (months) }\end{array}$} & \multirow{2}{*}{$\begin{array}{l}\text { Survival } \\
\text { state }\end{array}$} & \multicolumn{2}{|c|}{$\begin{array}{l}\text { Scoring of } \\
\text { PGRMC1 }\end{array}$} & \multicolumn{2}{|c|}{$\begin{array}{l}\text { Scoring of } \\
\text { ATP1A1 }\end{array}$} & \multicolumn{2}{|c|}{$\begin{array}{c}\text { Scoring of } \\
\text { p-AKT }\end{array}$} \\
\hline & & & & & & RCT & $\mathrm{PKT}$ & $\mathrm{RCT}$ & $\mathrm{PKT}$ & $\mathrm{RCT}$ & PKT \\
\hline 1 & 42 & Male & I-II & 74 & Survival & 4 & 2 & 1 & 6 & 4 & 1 \\
\hline 2 & 43 & Female & I & 73 & Survival & 3 & 3 & 0 & 9 & 4 & 0 \\
\hline 3 & 76 & Female & II & 73 & Survival & 6 & 2 & 1 & 6 & 2 & 0 \\
\hline 4 & 48 & Female & I & 36 & Death & 3 & 2 & 0 & 4 & 2 & 1 \\
\hline 5 & 66 & Female & III & 6 & Death & 1 & 4 & 0 & 12 & 6 & 0 \\
\hline 6 & 29 & Male & II & 106 & Survival & 3 & 4 & 0 & 9 & 0 & 0 \\
\hline 7 & 66 & Female & II & 106 & Survival & 9 & 2 & 1 & 6 & 6 & 1 \\
\hline 8 & 71 & Male & II & 106 & Survival & 6 & 2 & 3 & 12 & 1 & 0 \\
\hline 9 & 62 & Male & I & 105 & Survival & 4 & 4 & 0 & 12 & 1 & 1 \\
\hline 10 & 57 & Female & I & 41 & Death & 9 & 2 & 1 & 4 & 4 & 1 \\
\hline 11 & 65 & Female & I-II & 70 & Survival & 4 & 4 & 4 & 12 & 2 & 1 \\
\hline 12 & 50 & Female & I-II & 70 & Survival & 6 & 2 & 3 & 12 & 4 & 0 \\
\hline 13 & 62 & Male & I & 70 & Survival & 8 & 4 & 2 & 9 & 8 & 1 \\
\hline 14 & 79 & Male & II-III & 32 & Death & 6 & 4 & 1 & 8 & 9 & 0 \\
\hline 15 & 73 & Female & I & 67 & Death & 8 & 3 & 8 & 9 & 1 & 1 \\
\hline 16 & 44 & Male & I & 105 & Survival & 3 & 6 & 1 & 12 & 4 & 0 \\
\hline 17 & 52 & Female & I-II & 105 & Survival & 9 & 2 & 0 & 12 & 8 & 0 \\
\hline 18 & 73 & Female & I-II & 105 & Survival & 2 & 2 & 1 & 8 & 0 & 0 \\
\hline 19 & 73 & Male & II & 105 & Survival & 1 & 2 & 1 & 9 & 0 & 0 \\
\hline 20 & 44 & Male & I-II & 105 & Survival & 6 & 2 & 0 & 12 & 1 & 0 \\
\hline 21 & 78 & Male & II & 61 & Death & 12 & 2 & 0 & 6 & 0 & 0 \\
\hline 22 & 55 & Male & II & 2 & Death & 2 & 2 & 0 & 4 & 3 & 0 \\
\hline 23 & 49 & Female & I & 104 & Survival & 1 & 6 & 0.5 & 9 & 0 & 0 \\
\hline 24 & 61 & Male & I & 103 & Survival & 2 & 2 & 1 & 6 & 0 & 2 \\
\hline 25 & 52 & Female & I & 68 & Survival & 2 & 2 & 1 & 6 & 0 & 1 \\
\hline 26 & 67 & Female & II-III & 8 & Death & 4 & 6 & 0 & 12 & 4 & 1 \\
\hline 27 & 52 & Male & II & 103 & Survival & 4 & 2 & 8 & 6 & 1 & 0 \\
\hline 28 & 62 & Male & II-III & 72 & Death & 9 & 4 & 3 & 12 & 4 & 1 \\
\hline 29 & 44 & Female & I-II & 103 & Survival & 6 & 4 & 0.5 & 6 & 2 & 0 \\
\hline 30 & 60 & Female & I-II & 101 & Survival & 9 & 4 & 6 & 8 & 0 & 0 \\
\hline 31 & 57 & Female & III & 101 & Survival & 4 & 2 & 0 & 9 & 8 & 0 \\
\hline 32 & 48 & Female & I & 101 & Survival & 6 & 2 & 1 & 12 & 3 & 1 \\
\hline 33 & 72 & Male & II & 101 & Survival & 6 & 4 & 0 & 12 & 4 & 0 \\
\hline 34 & 42 & Female & I & 35 & Death & 8 & 6 & 2 & 2 & 3 & 1 \\
\hline 35 & 65 & Male & II & 34 & Death & 12 & 2 & 0 & 9 & 3 & 0 \\
\hline 36 & 78 & Female & I & 80 & Death & 4 & 4 & 1 & 4 & 1 & 1 \\
\hline 37 & 44 & Female & I & 100 & Survival & 6 & 2 & 0.5 & 8 & 6 & 0 \\
\hline 38 & 60 & Male & I-II & 100 & Survival & 8 & 4 & 1 & 9 & 2 & 0 \\
\hline 39 & 50 & Male & I & 100 & Survival & 1 & 3 & 0 & 9 & 0 & 2 \\
\hline 40 & 57 & Male & III & 3 & Death & 6 & 4 & 0 & 2 & 0 & 1 \\
\hline 41 & 57 & Female & I & 99 & Survival & 4 & 4 & 1 & 12 & 1 & 0 \\
\hline 42 & 65 & Male & I-II & 99 & Survival & 8 & 3 & 4 & 6 & 6 & 1 \\
\hline 43 & 71 & Female & II & 48 & Death & 9 & 6 & 3 & 9 & 8 & 2 \\
\hline 44 & 39 & Female & II & 99 & Survival & 8 & 4 & 4 & 12 & 2 & 1 \\
\hline 45 & 72 & Female & I-II & 61 & Death & 6 & 9 & 2 & 12 & 2 & 1 \\
\hline 46 & 54 & Male & III & 8 & Death & 3 & 4 & 0 & 9 & 0 & 0 \\
\hline 47 & 55 & Male & II & 99 & Survival & 6 & 4 & 0 & 9 & 2 & 4 \\
\hline 48 & 57 & Male & I & 49 & Death & 2 & 6 & 0 & 9 & 8 & 0 \\
\hline 49 & 48 & Female & I & 98 & Survival & 8 & 9 & 4 & 12 & 6 & 4 \\
\hline
\end{tabular}


Table II. Continued.

\begin{tabular}{|c|c|c|c|c|c|c|c|c|c|c|c|}
\hline \multirow{2}{*}{$\begin{array}{l}\text { Case } \\
\text { no. }\end{array}$} & \multirow{2}{*}{$\begin{array}{c}\text { Age } \\
\text { (years) }\end{array}$} & \multirow[b]{2}{*}{ Sex } & \multirow{2}{*}{$\begin{array}{l}\text { TNM } \\
\text { stage }\end{array}$} & \multirow{2}{*}{$\begin{array}{l}\text { Survival time } \\
\quad \text { (months) }\end{array}$} & \multirow{2}{*}{$\begin{array}{c}\text { Survival } \\
\text { state }\end{array}$} & \multicolumn{2}{|c|}{$\begin{array}{l}\text { Scoring of } \\
\text { PGRMC1 }\end{array}$} & \multicolumn{2}{|c|}{$\begin{array}{c}\text { Scoring of } \\
\text { ATP1A1 }\end{array}$} & \multicolumn{2}{|c|}{$\begin{array}{c}\text { Scoring of } \\
\text { p-AKT }\end{array}$} \\
\hline & & & & & & $\mathrm{RCT}$ & PKT & $\mathrm{RCT}$ & PKT & $\mathrm{RCT}$ & PKT \\
\hline 50 & 48 & Male & III-IV & 98 & Survival & 4 & 9 & 0 & 9 & 1 & 1 \\
\hline 51 & 70 & Male & I & 98 & Survival & 2 & 6 & 1 & 4 & 0 & 0 \\
\hline 52 & 77 & Male & I-II & 59 & Death & 2 & 2 & 0 & 9 & 1 & 1 \\
\hline 53 & 37 & Male & I-II & 98 & Survival & 4 & 2 & 0 & 12 & 0 & 0 \\
\hline 54 & 75 & Male & II & 98 & Survival & 6 & 6 & 0.5 & 9 & 0 & 0 \\
\hline 55 & 51 & Male & II & 98 & Survival & 8 & 4 & 0 & 8 & 1 & 0 \\
\hline 56 & 82 & Female & II & 62 & Death & 6 & 2 & 0 & 6 & 0 & 1 \\
\hline 57 & 64 & Male & I-II & 97 & Survival & 1 & 6 & 1 & 6 & 0 & 0 \\
\hline 58 & 66 & Female & II & 32 & Death & 9 & 4 & 1 & 9 & 6 & 1 \\
\hline 59 & 55 & Female & I & 97 & Survival & 9 & 4 & 1 & 12 & 0 & 0 \\
\hline 60 & 55 & Male & II & 97 & Survival & 6 & 6 & 0 & 9 & 0 & 0 \\
\hline 61 & 61 & Female & III & 66 & Death & 6 & 2 & 0 & 0 & 2 & 0 \\
\hline 62 & 54 & Male & I & 97 & Survival & 9 & 2 & 1 & 6 & 0 & 1 \\
\hline 63 & 59 & Male & III & 18 & Death & 8 & 1 & 0 & 6 & 0 & 0 \\
\hline 64 & 66 & Male & II & 95 & Survival & 8 & 2 & 4 & 9 & 9 & 4 \\
\hline 65 & 73 & Female & I & 95 & Survival & 6 & 6 & 0 & 12 & 2 & 2 \\
\hline 66 & 71 & Male & I & 94 & Survival & 2 & 4 & 1 & 9 & 1 & 0 \\
\hline 67 & 54 & Male & II & 93 & Survival & 2 & 2 & 0 & 4 & 0 & 0 \\
\hline 68 & 46 & Female & I & 93 & Survival & 4 & 6 & 0 & 8 & 1 & 2 \\
\hline 69 & 55 & Male & I & 92 & Survival & 1 & 4 & 1 & 4 & 0 & 0 \\
\hline 70 & 61 & Male & II & 92 & Survival & 9 & 2 & 1 & 12 & 6 & 4 \\
\hline 71 & 51 & Male & II & 92 & Survival & 2 & 2 & 0 & 9 & 0 & 0 \\
\hline 72 & 70 & Female & I & 92 & Survival & 6 & 4 & 1 & 9 & 2 & 1 \\
\hline 73 & 55 & Female & I & 92 & Survival & 8 & 2 & 2 & 6 & 1 & 1 \\
\hline 74 & 60 & Male & II & 45 & Death & 9 & 2 & 0 & 4 & 9 & 0 \\
\hline 75 & 64 & Male & I & 92 & Survival & 12 & 6 & 3 & 6 & 4 & 1 \\
\hline 76 & 57 & Female & II & 92 & Survival & 2 & 4 & 8 & 12 & 0 & 1 \\
\hline 77 & 55 & Male & I & 92 & Survival & 2 & 6 & 0 & 12 & 1 & 1 \\
\hline 78 & 64 & Female & II & 73 & Death & 8 & 4 & 0 & 9 & 8 & 0 \\
\hline 79 & 70 & Male & I & 90 & Survival & 9 & 4 & 2 & 6 & 0 & 0 \\
\hline 80 & 64 & Male & II & 30 & Death & 8 & 6 & 2 & 8 & 8 & 1 \\
\hline
\end{tabular}

RCT, renal cell carcinoma tissue; PKT, paracancerous kidney tissue.
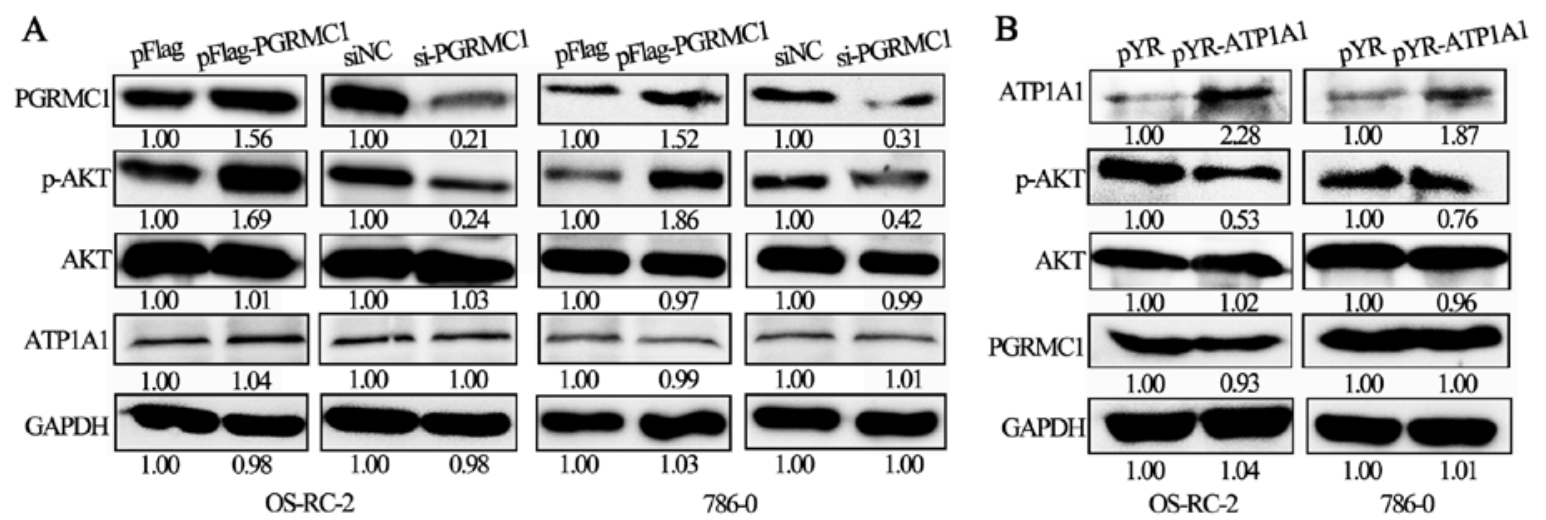

Figure 3. PGRMC1 upregulation and ATP1A1 downregulation both enhance AKT phosphorylation in RCC cells. (A) The expression levels of ATP1A1 and p-AKT were respectively assessed in RCC cells in response to overexpression or inhibition of PGRMC1 expression. pFlag-PGRMC1, PGRMC1-containing expression plasmid; pFlag, the empty expression vector; si-PGRMC1, PGRMC1-specific siRNA sequences; siNC, nonspecific oligonucleotides. (B) The expression levels of PGRMC1 and p-AKT were respectively assessed in RCC cells following transient transfection of pYR-ATP1A1 plasmids. The p-AKT was decreased in ATP1A1-overexpressing RCC cells. pYR, the empty expression plasmid; pYR-ATP1A1, ATP1A1-containing expression plasmid; p-AKT, phosphorylated AKT; RCC, renal cell carcinoma. 
A

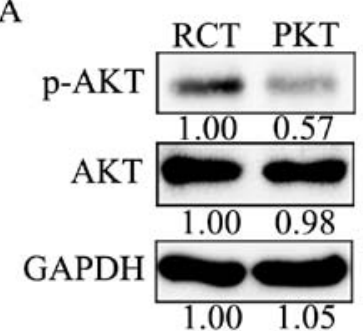

$\mathrm{C}$

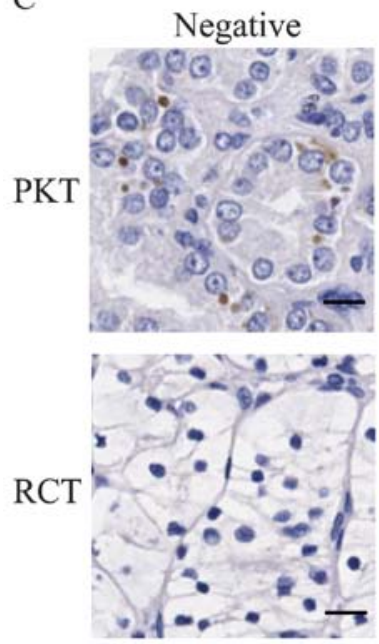

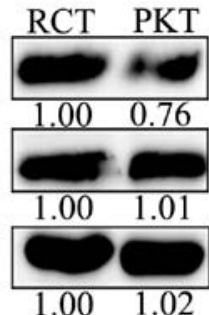

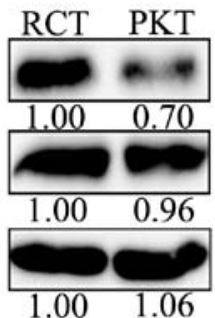

B

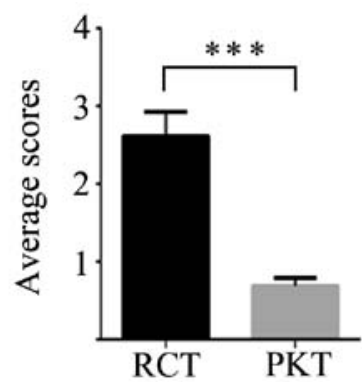

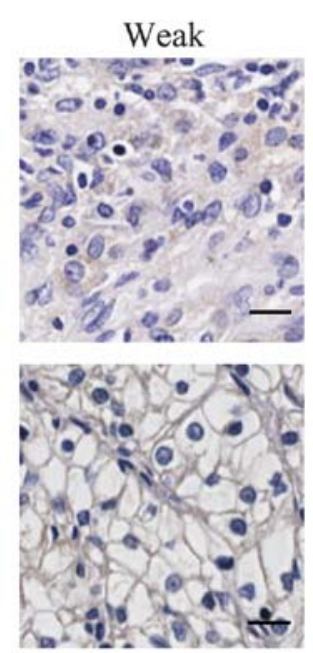
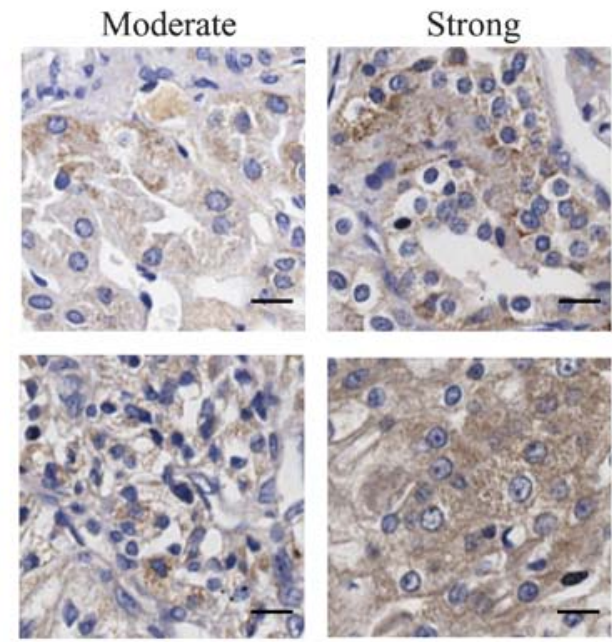

Figure 4. p-AKT levels in RCTs and PKTs as detected by western blotting and IHC. (A) p-AKT and AKT were assessed in three randomly selected RCTs and their counterparts. (B) The average immunoreactivity score of p-AKT was $2.61 \pm 0.32$ in $80 \mathrm{RCTs}$, which was higher than the average staining score $0.69 \pm 0.11$ in 80 corresponding PKTs $\left({ }^{* * *} \mathrm{P}<0.001\right)$. (C) A negative, weak, moderate and strong staining pattern of p-AKT was respectively shown in RCTs and PKTs. RCTs, renal cell carcinoma tissues; PKTs, para-cancerous kidney tissues; p-AKT, phosphorylated AKT. The red arrow indicates positive protein expression. Scale bar, $100 \mu \mathrm{m}$ (original magnification x200). IHC, immunohistochemistry.

Table III. Overall survival analysis of the combination of PGRMC1 and ATP1A1.

\begin{tabular}{lcccc}
\hline & & \multicolumn{2}{c}{7 -year OS Rate } \\
\cline { 3 - 5 } Markers & No. of & & \\
\cline { 3 - 5 } & patients & $(\%)$ & P-value \\
\hline PGRMC1 & & & $<0.05$ \\
$\quad$ Low & 34 & 76.0 & \\
High & 46 & 62.7 & \\
ATP1A1 & & & $<0.05$ \\
Negative & 33 & 54.5 & \\
Positive & 47 & 78.1 & \\
PGRMC1/ATP1A1 & & & $<0.05$ \\
Low PGRMC1+Positive ATP1A1 & 16 & 92.3 & \\
Low PGRMC1+Negative ATP1A1 & 18 & 61.1 & \\
High PGRMC1+Positive ATP1A1 & 31 & 70.7 & \\
High PGRMC1+Negative ATP1A1 & 15 & 46.7 & \\
\hline
\end{tabular}

OS, overall survival.

$p$-AKT upregulation is associated with the poor survival of RCC patients. To further explore the association of the interplaying signaling molecule p-AKT by PGRMC1 and ATP1A1 in RCC development, we analyzed p-AKT expression in RCTs. The p-AKT levels were increased in RCTs compared with their

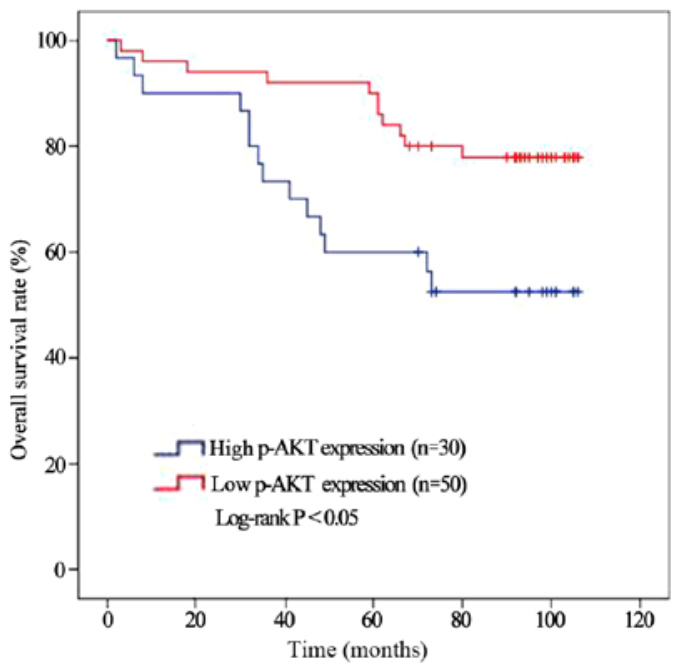

Figure 5. Associations between p-AKT expression and OS of RCC patients. The Kaplan-Meier estimates showed that patients with low p-AKT levels had a higher overall survival rate $(\mathrm{P}=0.011$ by the $\log$-rank test). $\mathrm{RCC}$, renal cell carcinoma; p-AKT, phosphorylated AKT; OS, overall survival.

corresponding PKTs by western blot analysis (Fig. 4A). In addition, we evaluated p-AKT expression in 80 pairs of RCTs and PKTs by IHC. The average immunoreactivity score of p-AKT was $2.61 \pm 0.32$ in $80 \mathrm{RCTs}$, which was significantly higher than the average staining score $0.69 \pm 0.11$ in PKTs (Fig. 4B). The negative, weak, moderate and strong staining patterns of p-AKT are respectively shown in RCTs and PKTs (Fig. 4C). 

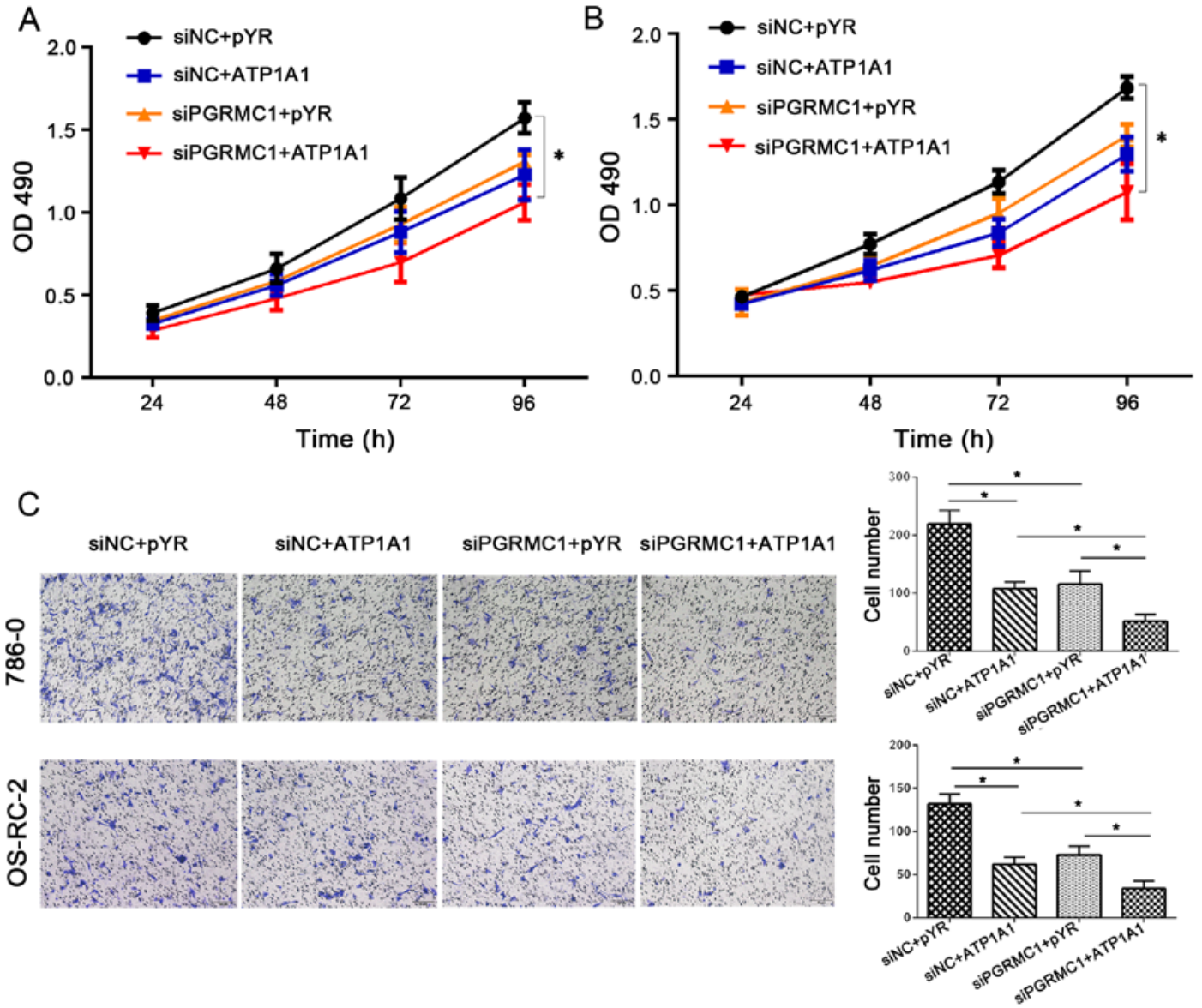

Figure 6. Combined regulation of PGRMC1 downregulation and ATP1A1 upregulation efficiently inhibited RCC cell proliferation and migration. Compared with the control group, co-transfection of pYR-ATP1A1 and siPGRMC1 more efficiently inhibited cell proliferation in (A) 786-O and (B) OS-RC-2 cells. (C) Co-transfection with pYR-ATP1A1 and siPGRMC1 significantly suppressed cell migration than each single transfection in RCC cells. The experiment was performed in triplicate, and data are shown as mean $\pm \mathrm{SD},{ }^{*} \mathrm{P}<0.05$. siNC+pYR, co-transfection with the empty expression plasmid (pYR) and nonspecific oligonucleotides (siNC); siNC+ATP1A1, co-transfection with the ATP1A1-containing expression plasmid (pYR-ATP1A1) and nonspecific oligonucleotides (siNC); si-PGRMC1+pYR, co-transfection the empty expression plasmid (pYR) and PGRMC1-specific siRNA sequences (siPGRMC1); si-PGRMC1+ATP1A1, co-transfection with the ATP1A1-containing expression plasmid (pYR-ATP1A1) and PGRMC1-specific siRNA sequences (si-PGRMC1); RCC, renal cell carcinoma.

A
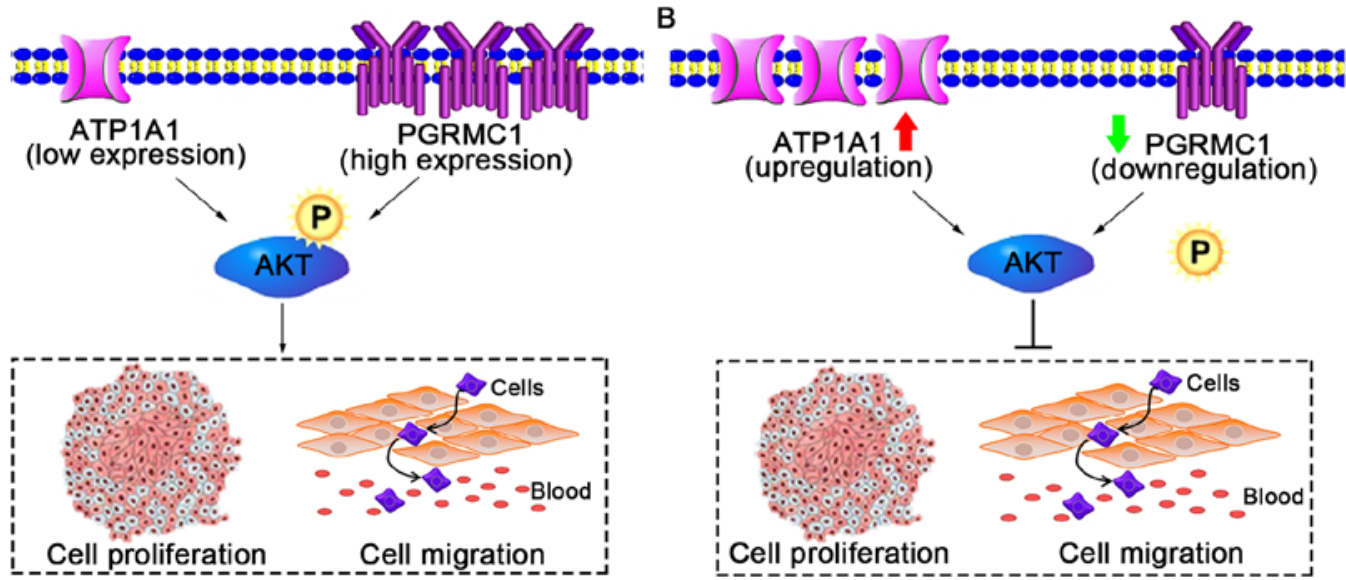

Figure 7. Schematic summary of the combined roles of ATP1A1 and PGRMC1 in RCC cells. (A) In RCC cells, the endogenous high level of PGRMC1 and low level of ATP1A1 both activated p-AKT, and consequently promoted cell proliferation and cell migration. (B) As a gene therapy strategy in vitro, PGRMC1 knockdown in combination with ATP1A1 upregulation demonstrated synergistic inhibitory effects on RCC cell growth and migration by suppressing p-AKT. p-AKT, phosphorylated AKT; (P): phosphorylation.

Furthermore, we investigated the association of p-AKT with RCC patient survival outcomes. The Kaplan-Meier method indicated RCC patients with a low p-AKT expression $(n=50)$ had a significant higher survival rate than those patients with a high p-AKT expression $(n=30)$ (Fig. 5, $\mathrm{P}=0.011$ ). 
Combined regulation of PGRMC1 downregulation and ATP1A1 upregulation efficiently inhibits cell proliferation and migration. We desired to know whether a therapy targeting both PGRMC1 and ATP1A1 would have a better effect in vitro. Compared with the control group, co-transfection of pYR-ATP1A1 and siPGRMC1 exerted more enhanced inhibitory effects on cell proliferation (Fig. 6A and $\mathrm{B}$ ) in 786-O and OS-RC-2 cells.

Meanwhile, cell migration by acting on PGRMC1/ATP1A1 proteins was significantly decreased by approximately $50 \%$ compared with targeting a single protein in the RCC cell lines (Fig. 6C) $(\mathrm{P}<0.05)$. We measured cell migration under the condition of PGRMC1 downregulation combined with ATP1A1 upregulation. The number of migrating cells was 34 following a combined regulation of PGRMC1 downregulation and ATP1A1 upregulation in the OS-RC-2 cells (Fig. 6C, the right bar marked with siPGRMC1+ATP1A1). On the other hand, the mean migrating cell number was 73 in OS-RC-2 cells following inhibition of PGRMC1 expression by siRNA, and the cell number was 62 in OS-RC-2 cells by only increasing the ATP1A1 level. A similar result was obtained in the 786-O cells. These results confirmed that the synergistic regulation of PGRMC1 downregulation along with ATP1A1 upregulation improved tumor inhibition potentials in RCC cells, which could contribute to the longer survival of RCC patients with low PGRMC1/positive ATP1A1 levels (Fig. 2).

\section{Discussion}

The present study demonstrated that PGRMC1 and ATP1A1 have opposite roles in regards to RCC growth. PGRMC1 is a tumor gene and ATP1A1 is a cancer suppressor (Fig. 7A). Although the expression levels of these two proteins are independent, elevated PGRMC1 and downregulated ATP1A1 in RCC cells can both activate the cellular p-AKT level which contributes to cell proliferation and migration (Fig. 7A). Thus, we focused on exploring the performance of combining ATP1A1 and PGRMC1 as a prognostic marker for RCC. RCC patients with low PGRMC1/positive ATP1A1 expression had a better OS rate (Fig. 2). On the contrary, a high PGRMC1/negative ATP1A1 expression predicted a worse survival outcome. Furthermore, combined gene therapy in vitro demonstrated that low PGRMC1/positive ATP1A1 exerts synergistic inhibition effects on RCC cell growth and migration by co-suppressing AKT phosphorylation (Fig. 7B). The activation of the PI3K-AKT signaling pathway has been shown to play an important role in many cancer types (34). Several studies suggest that progesterone accumulation could promote AKT phosphorylation in breast epithelial and ovarian cancer cells $(4,32)$. PGRMC1 knockdown can reduce phosphorylation of certain downstream EGFR targets, including AKT and ERK in HCT-116 cells (8). For ATP1A1, $\mathrm{Na}^{+} / \mathrm{K}^{+}$-ATPase inhibitors activate PI3K/AKT signaling pathways (33). Therefore, there could be indirect interactions between PGRMC1 and ATP1A1 by regulation of AKT phosphorylation. In addition, p-AKT expression was validated to be significantly higher in RCTs than that in PKTs. The Kaplan-Meier analysis indicated that RCC patients with a low $\mathrm{p}$-AKT expression had a significantly higher survival rate than those patients with a high $\mathrm{p}$-AKT expression.
Despite great improvements in surgical techniques for RCC treatment, the diagnosis and prognosis of RCC are still challenging. Thousands of proteins have been investigated as candidate cancer biomarkers. However, most of them do not have promising sensitivity and specificity for cancer prognosis. Since single biomarker may often fail to predict the survival outcomes for RCC patients, the combination of multiple biomarkers is widely discussed to improve prognosis (20). For example, osteopontin combined with CD44 improved diagnostic sensitivities in non-small cell lung cancer and hepatocellular carcinoma $(21,22)$. Based on our therapy targeting both PGRMC1 and ATP1A1 in vitro, the combined analysis of multiple biomarkers can also facilitate the development of efficient multi-target treatments in precision medicine.

In summary, the combined analysis of two biomarkers (PGRMC1 and ATP1A1) indicates enhanced prognosis for RCC patients. The therapy targeting the two biomarkers in vitro suggests its utility in precision medicine practice.

\section{Acknowledgements}

Not applicable.

\section{Funding}

The present study was financially supported by the grants from the National 863 High Tech Foundation (no. 2014AA020608), the National Key Basic Research Program of China (nos. 2013CB911303 and 2011CB910703), the National Natural Sciences Foundation of China (nos. 31470810 and 30970654), the Science and Technology Department of Sichuan Province (no. 2017JY0232) and the Health and Family Planning Commission of Sichuan Province (no. 17ZD045).

\section{Availability of data and materials}

The datasets used during the present study are available from the corresponding author upon reasonable request.

\section{Authors' contributions}

YH, DZ and XW performed the experiments. PZ, ZX and SD analyzed the clinical samples. HL, HZ and NX analyzed the data. SL conceived and instructed the experiments. All authors read and approved the manuscript and agree to be accountable for all aspects of the research in ensuring that the accuracy or integrity of any part of the work are appropriately investigated and resolved.

\section{Ethics approval and consent to participate}

All tissues were obtained from West China Hospital, Sichuan University (Chengdu, China) with the patient informed consent guidelines established. Prior review, consent, and approval for this study were obtained from the Institutional Ethics Committee of State Key Laboratory of Biotherapy, West China Hospital of Sichuan University.

\section{Patient consent for publication}

Not applicable. 


\section{Competing interests}

The authors declare that they have no competing interests.

\section{References}

1. Hsieh JJ, Purdue MP, Signoretti S, Swanton C, Albiges L Schmidinger M, Heng DY, Larkin J and Ficarra V: Renal cell carcinoma. Nat Rev Dis Primers 3: 17009, 2017.

2. Posadas EM, Limvorasak S and Figlin RA: Targeted therapies for renal cell carcinoma. Nat Rev Nephrol 13:496-511, 2017.

3. Cahill MA, Jazayeri JA, Catalano SM, Toyokuni S, Kovacevic Z and Richardson DR: The emerging role of progesterone receptor membrane component 1 (PGRMC1) in cancer biology. Biochim Biophys Acta 1866: 339-349, 2016

4. Zhu X, Han Y, Fang Z, Wu W, Ji M, Teng F, Zhu W, Yang X, Jia $X$ and Zhang C: Progesterone protects ovarian cancer cells from cisplatin-induced inhibitory effects through progesterone receptor membrane component $1 / 2$ as well as AKT signaling. Oncol Rep 30: 2488-2494, 2013.

5. Friel AM, Zhang L, Pru CA, Clark NC, McCallum ML, Blok LJ, Shioda T, Peluso JJ, Rueda BR and Pru JK: Progesterone receptor membrane component 1 deficiency attenuates growth while promoting chemosensitivity of human endometrial xenograft tumors. Cancer Lett 356: 434-442, 2015.

6. Clark NC, Friel AM, Pru CA, Zhang L, Shioda T, Rueda BR, Peluso JJ and Pru JK: Progesterone receptor membrane component 1 promotes survival of human breast cancer cells and the growth of xenograft tumors. Cancer Biol Ther 17: 262-271, 2016.

7. Mir SU, Ahmed IS, Arnold S and Craven RJ: Elevated progesterone receptor membrane component $1 /$ sigma-2 receptor levels in lung tumors and plasma from lung cancer patients. Int J Cancer 131: E1-9, 2012.

8. Kabe Y, Nakane T, Koike I, Yamamoto T, Sugiura Y, Harada E, Sugase K, Shimamura T, Ohmura M, Muraoka K, et al

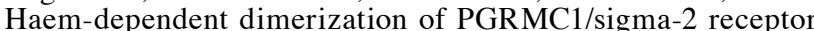
facilitates cancer proliferation and chemoresistance. Nat Commun 7: 11030, 2016.

9. Zhuang L, Xu L, Wang P, Jiang Y, Yong P, Zhang C, Zhang H, Meng $Z$ and Yang P: $\mathrm{Na}^{+} / \mathrm{K}^{+}$-ATPase $\alpha 1$ subunit, a novel therapeutic target for hepatocellular carcinoma. Oncotarget 6 : 28183-28193, 2015.

10. Lefranc F and Kiss R: The sodium pump alphal subunit as a potential target to combat apoptosis-resistant glioblastomas. Neoplasia 10: 198-206, 2008.

11. Mathieu V, Pirker C, Martin de Lassalle E, Vernier M, Mijatovic T, DeNeve N, Gaussin JF, Dehoux M, Lefranc F, Berger W and Kiss R: The sodium pump alphal sub-unit: A disease progression-related target for metastatic melanoma treatment. J Cell Mol Med 13: 3960-3972, 2009.

12. Mijatovic T, Roland I, Van Quaquebeke E, Nilsson B, Mathieu A, Van Vynckt F, Darro F, Blanco G, Facchini V and Kiss R: The alphal subunit of the sodium pump could represent a novel target to combat non-small cell lung cancers. J Pathol 212: 170-179, 2007.

13. Wu IC, Chen YK, Wu CC, Cheng YJ, Chen WC, Ko HJ, Liu YP, Chai CY, Lin HS, Wu DC and Wu MT: Overexpression of ATPase $\mathrm{Na}+/+$ transporting alpha 1 polypeptide, ATP1A1, correlates with clinical diagnosis and progression of esophageal squamous cell carcinoma. Oncotarget 7: 85244-85258, 2016

14. Sakai H, Suzuki T, Maeda M, Takahashi Y, Horikawa N, Minamimura T, Tsukada $\mathrm{K}$ and Takeguchi N: Up-regulation of $\mathrm{Na}^{+}, \mathrm{K}^{+}$-ATPase $\alpha 3$-isoform and down-regulation of the $\alpha 1$-isoform in human colorectal cancer. FEBS Lett 563: 151-154, 2004.

15. Mobasheri A, Fox R, Evans I, Cullingham F, Martín-Vasallo P and Foster CS: Epithelial Na, K-ATPase expression is down-regulated in canine prostate cancer; a possible consequence of metabolic transformation in the process of prostate malignancy. Cancer Cell Int 3: 8, 2003.

16. Li Z, Zhang Z, Xie JX, Li X, Tian J, Cai T, Cui H, Ding H, Shapiro JI and Xie Z: Na/K-ATPase mimetic pNaKtide peptide inhibits the growth of human cancer cells. J Biol Chem 286: 32394-32403, 2011.
17. Zhang D, Xia X, Wang X, Zhang P, Lu W, Yu Y, Deng S, Yang H, Zhu H, Xu N, et al: PGRMC1 is a novel potential tumor biomarker of human renal cell carcinoma based on quantitative proteomic and integrative biological assessments. PLoS One 12: e0170453, 2017.

18. Zhang D, Zhang P, Yang P, He Y, Wang X, Yang Y, Zhu H, Xu N and Liang S: Downregulation of ATP1A1 promotes cancer development in renal cell carcinoma. Clin Proteomics 14: 15, 2017.

19. Feng X, Li H, Kornaga EN, Dean M, Lees-Miller SP, Riabowol K, Magliocco AM, Morris D, Watson PH, Enwere EK, et al: Low Ki67/high ATM protein expression in malignant tumors predicts favorable prognosis in a retrospective study of early stage hormone receptor positive breast cancer. Oncotarget 7: 85798-85812, 2016.

20. Liang S, Xu Z, Xu X, Zhao X, Huang C and Wei Y: Quantitative proteomics for cancer biomarker discovery. Comb Chem High Throughput Screen 15: 221-231, 2012.

21. Sun BS, Li Y, Zhang ZF, You J and Wang CL: Osteopontin combined with CD44v6, a novel prognostic biomarker in non-small cell lung cancer undergoing curative resection. Ann Thorac Surg 96: 1943-1951, 2013.

22. Yang GH, Fan J, Xu Y, Qiu SJ, Yang XR, Shi GM, Wu B, Dai Z, Liu YK, Tang ZY and Zhou J: Osteopontin combined with CD44, a novel prognostic biomarker for patients with hepatocellular carcinoma undergoing curative resection. Oncologist 13: $1155-1165,2008$

23. Wu DH, Wang TT, Ruan DY, Li X, Chen ZH, Wen JY, Lin Q, Ma XK, Wu XY and Jia CC: Combination of ULK1 and LC3B improve prognosis assessment of hepatocellular carcinoma. Biomed Pharmacother 97: 195-202, 2017.

24. Zhu C, Wei J, Tian X, Li Y and Li X: Prognostic role of PPAR- $\gamma$ and PTEN in the renal cell carcinoma. Int J Clin Exp Pathol 8: 12668-12677, 2015.

25. Song YL, Yu R, Qiao XW, Bai CM, Lu CM, Xiao Y, Zhong DR, Chen J, Zhao YP, Zhang TP, et al: Prognostic relevance of $\mathrm{UCH}-\mathrm{L} 1$ and $\alpha$-internexin in pancreatic neuroendocrine tumors. Sci Rep 7: 2205, 2017.

26. Zisman A, Pantuck AJ, Dorey F, Said JW, Shvarts O, Quintana D, Gitlitz BJ, deKernion JB, Figlin RA and Belldegrun AS: Improved prognostication of renal cell carcinoma using an integrated staging system. J Clin Oncol 19: 1649-1657, 2001.

27. Liang S, Xu Y, Shen G, Zhao X, Zhou J, Li X, Gong F, Ling B, Fang L, Huang $C$ and Wei Y: Gene expression and methylation status of 14-3-3sigma in human renal carcinoma tissues. IUBMB Life 60: 534-540, 2008.

28. Jin X, Liu Y, Liu J, Lu W, Liang Z, Zhang D, Liu G, Zhu H, Xu N and Liang S: The overexpression of IQGAP1 and $\beta$-catenin is associated with tumor progression in hepatocellular carcinoma in vitro and in vivo. PLoS One 10: e0133770, 2015.

29. Chen B, Zeng X, He Y, Wang X, Liang Z, Liu J, Zhang P, Zhu H, $\mathrm{Xu} \mathrm{N}$ and Liang S: STC2 promotes the epithelial-mesenchymal transition of colorectal cancer cells through AKT-ERK signaling pathways. Oncotarget 7: 71400-71416, 2016.

30. Liang Z, Yang Y, He Y, Yang P, Wang X, He G, Zhang P, Zhu H, $\mathrm{Xu}$ N, Zhao X and Liang S: SUMOylation of IQGAP1 promotes the development of colorectal cancer. Cancer Lett 411: 90-99, 2017.

31. Dong Z, Chen Y, Peng Y, Wang F, Yang Z, Huang G, Chen Y, Yuan Z, Cao T and Peng Y: Concurrent CCR7 overexpression and RelB knockdown in immature dendritic cells induces immune tolerance and improves skin-graft survival in a murine model. Cell Physiol Biochem 42: 455-468, 2017.

32. Salazar M, Lerma-Ortiz A, Hooks GM, Ashley AK and Ashley RL: Progestin-mediated activation of MAPK and AKT in nuclear progesterone receptor negative breast epithelial cells: The role of membrane progesterone receptors. Gene 591: 6-13, 2016.

33. Wu J, Akkuratov EE, Bai Y, Gaskill CM, Askari A and Liu L: Cell signaling associated with $\mathrm{Na}^{+} / \mathrm{K}^{+}$-ATPase: activation of phosphatidylinositide 3-kinase IA/Akt by ouabain is independent of Src. Biochemistry 52: 9059-9067, 2013.

34. Zhang L, Wu J, Ling MT, Zhao L and Zhao KN: The role of the $\mathrm{PI} 3 \mathrm{~K} / \mathrm{Akt} / \mathrm{mTOR}$ signalling pathway in human cancers induced by infection with human papillomaviruses. Mol Cancer 14: 87, 2015. 